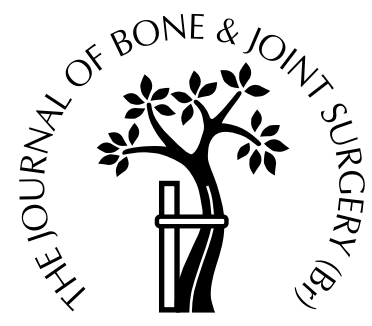

\title{
Levels of metal ions after small- and large- diameter metal-on-metal hip arthroplasty
}

\author{
M. T. Clarke, P. T. H. Lee, A. Arora, R. N. Villar \\ From Cambridge Lea Hospital, Cambridge University, England and SUNY-Upstate Medical \\ University, New York, USA
}

M

etal-on-metal (MOM) bearings for hip

arthroplasty are increasing in popularity. Concern remains, however, regarding the potential toxicological effects of the metal ions which these bearings release.

The serum levels of cobalt and chromium in 22 patients who had undergone MOM resurfacing arthroplasty were compared with a matched group of 22 patients who had undergone $28 \mathrm{~mm}$ MOM total hip arthroplasty (THA).

At a median of 16 months ( 7 to 56) after resurfacing arthroplasty, we found the median serum levels of cobalt and chromium to be $38 \mathrm{nmol} / \mathrm{l}(14$ to 44$)$ and $53 \mathrm{nmol} / \mathrm{l}$ (23 to 165 ) respectively. These were significantly greater than the levels after $28 \mathrm{~mm}$ MOM THA which were 22 $\mathrm{nmol} / \mathrm{l}(15$ to $87, \mathrm{p}=0.021)$ and $19 \mathrm{nmol} / \mathrm{l}(2$ to $58, \mathrm{p}<$ $0.001)$ respectively.

Since the upper limit for normal patients without implants is typically $5 \mathrm{nmol} / \mathrm{l}$, both groups had significantly raised levels of metal ions. MOM bearings of large diameter, however, result in a greater systemic exposure of cobalt and chromium ions than bearings of small diameter. This may be of relevance for potential long-term side-effects. It is not known to what extent this difference is due to corrosion of the surfaces of the component or of the wear particles produced.

J Bone Joint Surg [Br] 2003;85-B:913-7, Received 14 January 2003; Accepted 27 May 2003

M. T. Clarke, FRCS (Trauma \& Orth), Assistant Professor

Orthopaedic Surgery, SUNY-Upstate Medical University, 550 Harrison St, Suite 128, Syracuse, New York 13202, USA

P. T. H. Lee, MRCS, Clinical Research Associate

The Orthopaedic Research Unit, Cambridge University, Cambridge CB2 2QQ, UK

A. Arora, FRCS, Research Fellow

R. N. Villar, MS, FRCS, Consultant Orthopaedic Surgeon

The Cambridge Hip and Knee Unit, BUPA Cambridge Lea Hospital, 30 New Road, Impington, Cambridge CB4 9EL, UK.

Correspondence should be sent to Mr M. T. Clarke.

(c)2003 British Editorial Society of Bone and Joint Surgery doi:10.1302/0301-620X.85B6.14166 \$2.00
Metal-on-metal (MOM) bearings were first used in total hip arthroplasty (THA) over 40 years ago. ${ }^{1-3}$ Because of a limited understanding of the engineering of these bearings and early failures in some cases, they lost popularity to the lowfriction stainless-steel/ultra-high-molecular-weight polyethylene bearing developed by Charnley. ${ }^{4}$ Over the past 15 years, with an improved understanding of the aetiology of aseptic loosening and of the science of wear, there has been increased interest in the use of MOM bearings. ${ }^{5,6}$ Of the many engineering factors which have contributed to the success of the MOM bearing, the metallurgy, diametric bearing clearance, sphericity and surface finish are thought to be most important. ${ }^{7-9}$

All metal implants, especially those which include MOM bearings corrode at a rate determined, in part, by their surface area. ${ }^{10}$ Further, side-effects relate directly to the particles of metal which are produced and their subsequent fate within the body. Our hypothesis was that the production of wear debris, and thus metal ion release, would be less after resurfacing arthroplasty than after THA using a $28 \mathrm{~mm}$ MOM bearing. This was based on the theoretical fluid film lubrication and reduced potential for the production of wear debris which is thought to occur in MOM bearings of large diameter, despite the increased surface area available for corrosion with these implants. ${ }^{11}$

\section{Patients and Methods}

Evaluation of patients. All joint arthroplasties are prospectively registered on a computerised database. We contacted patients who had undergone either unilateral MOM or resurfacing arthroplasty at least six months earlier and asked them to attend dedicated clinics. They completed a questionnaire and provided a sample of blood for analysis of cobalt and chromium. Since we were interested in estimating the systemic release of metal ions from the implanted prostheses, we specifically addressed factors which could have affected the results. These included occupational exposure, the ingestion of prescription or non-prescription medications and the presence of other metal implants within the body; we also recorded the patient's weight in kilograms, the date after surgery in months and the level of activity.

In order to evaluate the level of activity, we devised a system which grouped the patients into one of four catego- 
ries, $\mathrm{A}, \mathrm{B}, \mathrm{C}$ or $\mathrm{D}$. To be considered in category $\mathrm{A}$, patients were allowed to have engaged in limited activity outside their home and unrestricted mobility at home. No sporting or activity-based recreational pastimes were followed. For category B, patients were expected to be more mobile outside the home and to walk up to two miles per day on average. Occasional light recreational activity was allowed, such as gardening or bowls. For category $\mathrm{C}$, patients were expected to be mobile for longer periods. Walking from two to five miles daily on average or to undertake regular light to moderate recreational activity such as tennis, golf or walking. For category D, patients were expected to walk more than five miles daily on average. Regular moderate to heavy recreational activity such as competitive sports, running or ski-ing, was also expected.

Exclusions. The following exclusion criteria were applied: 1) less than six months after surgery; 2) limited activity because of symptoms from the MOM THA; 3) clinical or radiological suspicion of loosening; 4) the presence of other metal foreign bodies including arthroplasties unless known to be made of titanium, titanium alloy (Ti6Al4V), or ceramic (zirconia or alumina); 5) occupational exposure to cobalt or chromium; 6) ingestion of multivitamins or medications containing cobalt or chromium such as vitamin B12; and 7) bilateral MOM bearings.

Matching. Once the patients had been reviewed, a matching process was performed between the two groups according to the following objective criteria: 1) date after surgery to within six months; 2) identical activity level group; and 3) body mass to within $10 \mathrm{~kg}$.

Blood sampling. Plastic consumables were certified to be free from cobalt and chromium by batch testing and were supplied by the Trace Metals Unit at the University of Southampton which performed the analyses.

We obtained blood using a disposable intravenous cannula. Once we had entered an appropriate antecubital vein, we immediately withdrew the central stainless-steel needle and left the outer plastic tube in situ. An initial $10 \mathrm{ml}$ of blood was withdrawn and discarded to avoid contamination with chromium from blood which may have been in touch with the steel tip of the needle. We subsequently withdrew a further $10 \mathrm{ml}$ of blood and transferred it into separate $2 \mathrm{ml}$ tubes containing lithium-heparin anticoagulant. We centrifuged the blood at $3000 \mathrm{rpm}$ for ten minutes and froze the plasma at $-80^{\circ} \mathrm{C}$.

Analysis of cobalt and chromium. We determined the levels of cobalt and chromium using inductively-coupled plasma mass spectrometry (ICP-MS) on a Perkin-Elmer SCIEX Elan 6100 DRC plus (Wellesley, Massachusetts). We ran the plasmas against a bovine serum calibration curve, spiked with $0,1,5,10,20$ and $50 \mu \mathrm{g} / 1$ of cobalt and chromium. Sample volumes of $100 \mu \mathrm{l}$ were diluted with deionised water and an internal standard $(100 \mu \mathrm{l}$ of rhodium solution at $100 \mu \mathrm{g} / \mathrm{l}$ for cobalt, and gallium solution for chromium) to eliminate imprecision caused by any fluctuations in the plasma temperature and instru- mental response. For the chromium analysis we used dynamic reaction cell (DRC) technology to minimise polyatomic interferences for measurement of ${ }^{52} \mathrm{Cr}$ with ammonia as the reactive gas. Internal quality control was provided by the certified reference material, Seronorm (Nycomed, Asker, Norway) and a bovine serum spiked with cobalt and chromium $(100 \mu \mathrm{l}$ of $1 \mu \mathrm{g} / \mathrm{ml}$ of Co and $\mathrm{Cr}$ into $20 \mathrm{ml}$ of serum to give internal quality control $\mathrm{A}$, and $200 \mu \mathrm{l}$ of $1 \mu \mathrm{g} / \mathrm{ml}$ of $\mathrm{Co} / \mathrm{Cr}$ into $20 \mathrm{ml}$ of serum to give IQC B). All reagents used were of Aristar quality (BDH, Poole, UK) and distilled, deionised water (Milli 'Q' system; Millipore, Billerica, Massachusetts) was used throughout.

Implants. The prostheses used in this study were either large-diameter resurfacings or standard-diameter $(28 \mathrm{~mm})$ MOM THAs.

We used two types of resurfacing, both of which are machined from cast cobalt-chromium-molybdenum (CoCrMo) alloy in accordance with British Standard (BS) 7252 part 4. The Birmingham hip resurfacing (BHR; Midland Medical Technologies, Birmingham, UK) is machined from 'as cast' material resulting in a carbide fraction of 5\%. The system has an uncemented, hydroxyapatite-coated, press-fit acetabulum and a cemented femoral component. The Cormet 2000 resurfacing arthroplasty (Corin Surgical, Cirencester, UK) is a totally uncemented device with a hydroxyapatite backing on both components. The cast alloy of the Cormet 2000 is subject to hot-isostatic pressing (HIPping) and solution annealing before the machining process which results in a carbide fraction of $2.3 \%$. The typical mean surface roughness ( $\mathrm{Ra}$ ) of both of these devices is of the order of $0.01 \mu \mathrm{m}$ with a diametric bearing clearance of 200 to $300 \mu \mathrm{m}$. The deviation from sphericity is typically less than $10 \mu \mathrm{m}$ determined either by co-ordinate measuring (Cormet 2000) or by roundness testing (BHR).

The $28 \mathrm{~mm}$ MOM bearing which we used is the articulating surface of a hybrid THA (Ultima MOM; Johnson \& Johnson, Leeds, UK). The stem is cemented and manufactured from wrought CoCrMo according to the American Society for Testing and Materials (ASTM) specification F1537. The acetabulum is a modular press-fit component with a titanium alloy (Ti6Al4V) shell. The acetabular liner with bearing surface is manufactured in accordance with ASTM F1537 and contains a relatively high carbon content. It is held within the shell by a taper-locking mechanism. The modular femoral head is also manufactured in accordance with ASTM F1537 but with a relatively low carbon content. The femoral head and acetabulum are manufactured to similar specifications of sphericity and surface roughness as the resurfacing designs.

Statistical analysis. We used the Mann-Whitney U test for data which were not normally distributed (serum cobalt, serum chromium, date after surgery). We used the paired Student $t$-test for normally distributed contiguous data (age, weight). 


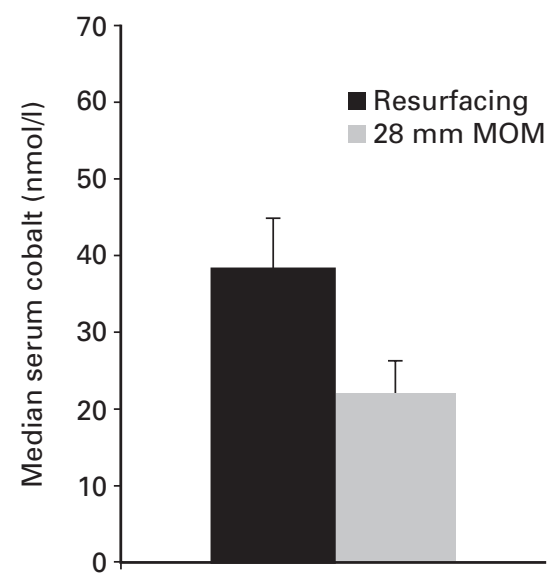

Fig. 1a

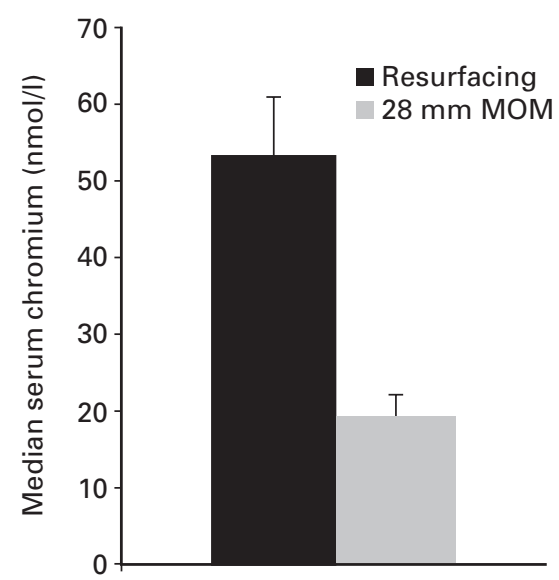

Fig. 1b

Median ( \pm SEM) serum levels of cobalt (a) and chromium (b) after resurfacing and 28 mm MOM arthroplasty.

Table I. Comparative data which relate to the resurfacing and $28 \mathrm{~mm}$ diameter prostheses used.

\begin{tabular}{|c|c|c|c|}
\hline & Resurfacing MOM $(n=22)$ & $\begin{array}{l}28 \text { mm Ultima MOM THA } \\
(n=22)\end{array}$ & p value \\
\hline Median serum cobalt in $\mathrm{nmol} / \mathrm{l}$ (range) & $38(14$ to 144$)$ & $22(15$ to 87$)$ & 0.0021 \\
\hline $\operatorname{BHR}(\mathrm{n}=16)$ & $35.5(14$ to 144$)$ & & $>0.05$ \\
\hline Cormet $2000(n=6)$ & $51(20$ to 117$)$ & & \\
\hline $\begin{array}{l}\text { Median serum chromium in } \mathrm{nmol} / \mathrm{l} \\
\text { (range) }\end{array}$ & $53(25$ to 165$)$ & $19(2$ to 58$)$ & 0.0001 \\
\hline $\operatorname{BHR}(\mathrm{n}=16)$ & $50(29$ to 165$)$ & & \\
\hline Cormet $2000(n=6)$ & $80(25$ to 129 & & $>0.05$ \\
\hline Mean age in years (range) & $53(39$ to 68$)$ & $60.9(39$ to 77$)$ & 0.016 \\
\hline Mean weight in $\mathrm{kg}$ (range) & $79.8(50.4$ to 105.2 & $78.8(54.9$ to 101.6$)$ & $>0.05$ \\
\hline \multicolumn{4}{|l|}{ Activity level } \\
\hline A & 2 & 2 & \multirow[t]{4}{*}{ Not applicable } \\
\hline B & 7 & 7 & \\
\hline $\mathrm{C}$ & 10 & 10 & \\
\hline $\mathrm{D}$ & 3 & 3 & \\
\hline $\begin{array}{l}\text { Median bearing surface diameter } \\
\text { (range) in } \mathrm{mm}\end{array}$ & 48 (38 to 54$)$ & 28 & Not applicable \\
\hline $\begin{array}{l}\text { Median date after surgery (range) } \\
\text { in months }\end{array}$ & $16(7$ to 56$)$ & $20(10$ to 43$)$ & $>0.05$ \\
\hline
\end{tabular}

\section{Results}

Matching (Table I). Using the matching criteria described, we were able to match 44 patients (22 from each group) with MOM bearings. The two groups were, therefore, not significantly different with respect to mean weight ( $\mathrm{p}>$ $0.05)$ or median date after surgery $(\mathrm{p}>0.05)$. The patients in the resurfacing group were, however, significantly younger by a mean of 7.9 years $(p=0.016)$, reflecting our indications for resurfacing in a younger age group.

Forty-two of the patients matched in all three categories (date after surgery, activity level and mass). Two were matched by weight and by level of activity but could not be exactly matched by date after surgery (43 months (THA) and 56 months (resurfacing)). Since both patients had had surgery at least 3.5 years earlier and were within a 13-month time frame of each other (without an alternative appropriate match), we felt that it was appropriate to include them for analysis. All matching was performed and patients were included or excluded before the serum metal levels were known.

Serum cobalt and chromium levels (Fig. 1). Since the serum levels had not been determined before surgery, we used a conservative threshold level of $5 \mathrm{nmol} / \mathrm{l}$ for both cobalt and chromium as the upper limit on which to calculate our multiplications of normal. This figure was chosen from a review of the literature on the values in normal individuals. $^{12-15}$ 
We found the median cobalt level to be 7.6 times normal (median $38 \mathrm{nmol} / \mathrm{l}, 14$ to 144 ) after resurfacing arthroplasty compared with 4.4 times normal (median $22 \mathrm{nmol} / \mathrm{l}, 15$ to 87) after $28 \mathrm{~mm}$ MOM THA $(\mathrm{p}=0.0021)$. We found the median chromium level to be 10.6 times normal $(53 \mathrm{nmol} / \mathrm{l}$, 25 to 165 ) after resurfacing arthroplasty compared with 3.8 times of normal $(19 \mathrm{nmol} / \mathrm{l}, 2$ to 58$)$ after THA ( $<<0.0001)$.

With the numbers available, we did not detect any significant difference in the serum levels of cobalt and chromium when comparing the BHR $(\mathrm{n}=16$, median $35.5 \mathrm{nmol} / \mathrm{l}$ and $50 \mathrm{nmol} / \mathrm{l}$, respectively) with the Cormet $2000(\mathrm{n}=6$, median $51 \mathrm{nmol} / \mathrm{l}$ and $80 \mathrm{nmol} / \mathrm{l}$, respectively).

\section{Discussion}

We have shown that resurfacing arthroplasty gives a significantly greater increase in serum cobalt and chromium concentrations than a $28 \mathrm{~mm}$ MOM THA when matched for level of activity, weight and date after surgery.

At a median time of 16 months after surgery ( 7 to 56), the median cobalt and chromium levels after resurfacing arthroplasty were $38 \mathrm{nmol} / \mathrm{l}$ and $54 \mathrm{nmol} / \mathrm{l}$, respectively, compared with the levels of $22 \mathrm{nmol} / \mathrm{l}$ and $19 \mathrm{nmol} / \mathrm{l}$, respectively, after $28 \mathrm{~mm}$ MOM THA. Furthermore, the maximum serum levels of cobalt and chromium recorded after resurfacing arthroplasty $(165 \mathrm{nmol} / \mathrm{l}$ and $144 \mathrm{nmol} / \mathrm{l}$, respectively) were double those after THA ( $87 \mathrm{nmol} / \mathrm{l}$ and $58 \mathrm{nmol} / \mathrm{l}$, respectively). With an upper limit of normal for both cobalt and chromium being typically $5 \mathrm{nmol} / \mathrm{l}$, these represent significant increases above physiological values. ${ }^{12-15}$ These findings are important since there is concern that chronic rises in serum cobalt and chromium may have long-term toxicological effects such as immune modulation, chromosomal damage and carcinogenesis. ${ }^{16-18}$

The serum levels of metal ions reported in our study for $28 \mathrm{~mm}$ Ultima MOM THA bearing are similar to those published for the $28 \mathrm{~mm}$ Metasul bearing (Centerpulse, Winterthur, Switzerland). In 1997 Brodner al al, ${ }^{12}$ reported serum cobalt concentrations of $18.6 \mathrm{nnmol} / \mathrm{l}$ at one year after surgery for 27 Metasul THAs, and in 2002 Savarino et al ${ }^{14}$ described serum cobalt and chromium concentrations of $16.4 \mathrm{nmol} / \mathrm{l}$ and $31.9 \mathrm{nmol} / \mathrm{l}$, respectively, at a median of two years after surgery for 26 Metasul THAs.

By contrast, to date there has been no published study which has adequately addressed the serum metal concentrations after resurfacing arthroplasty. In 1996, Jacobs et al ${ }^{19}$ reported the serum levels of cobalt and chromium after five resurfacing arthroplasties. One was a Wagner prosthesis with a titanium shell (Centerpulse, Winterthur, Switzerland) and four were McMinn prostheses (Corin Surgical, Cirencester, UK). However, one patient had bilateral prostheses, one had a contralateral CoCrMo THA and another had cobalt- and chromium-containing orthopaedic implants elsewhere in the body. Bearing in mind these confounding factors, the serum cobalt and chromium concentrations taken at a mean of one year after surgery ( 2 to 19 months) were $63.7 \mathrm{nmol} / \mathrm{l}(16.9$ to 162.2$)$ cobalt and $74.1 \mathrm{nmol} / \mathrm{l}$ (50.7 to 109.8) for chromium.

More definitive data regarding levels of metal ions after resurfacing arthroplasty are available only in abstracts from the proceedings of scientific meetings. At the 2001 meeting of the American Association of Orthopaedic Surgeons (AAOS), Skipor et $\mathrm{al}^{20}$ reported serum cobalt and chromium concentrations of $22.9 \mathrm{nmol} / 1$ and $43.3 \mathrm{nmol} / \mathrm{l}$, respectively, for ten resurfacings using the Conserve-Plus prosthesis (Wright Medical, Arlington, Texas). At the 2002 meeting of the Institution of Mechanical Engineers in London, Witzleb et $\mathrm{al}^{21}$ reported serum concentrations of 33 $\mathrm{nmol} / \mathrm{l}$ and $44 \mathrm{nmol} / \mathrm{l}$, respectively, at six months after 67 resurfacing arthroplasties using the BHR.

While it is certain that the metal ions must be released because of the combined effect of corrosion at the surface of the implant and the wear debris which is produced, the exact reasons for the differences observed between the two groups in our study are not clear. The potential list of causes is long and includes differences in the lubrication regimes as a result of metallurgy, diametric clearance, sphericity and surface finish. The large-diameter resurfacings are thought by some to benefit from fluid film lubrication and thus reduced production of wear debris. ${ }^{7,11}$ These engineering ideals, however, do not take into account the major aspects of biological variability, the potential for third-body wear and the concept of bearing microseparation. ${ }^{22,23}$ In this regard, it has been noted that $28 \mathrm{~mm}$ MOM bearings are resistant to microseparation during the normal gait cycle. ${ }^{24}$ It is not known if the same is true of resurfacing arthroplasties since their diametric clearance is typically much greater and the potential for a 'suction fit' may be less.

While all the bearings in our study were manufactured from $\mathrm{CoCrMo}$, it should be noted that this designation encompasses a heterogenous group of alloys which differ in metallurgy, wear resistance and corrosion. The BHR and Cormet 2000 are machined from cast alloy containing a carbide fraction of 5\%, but the Cormet 2000 is further heattreated before machining which reduces the carbide fraction to $2.3 \%$. The benefits or otherwise of carbides in CoCrMobearing surfaces is a controversial issue. In general, the greater the carbide content, the greater is the hardness and thus potential for resistance to wear, although the relationship is not straightforward. A problem with enhanced carbide levels is a reduction in corrosion resistance. ${ }^{25}$ This may potentially account for the low levels of metal ions observed in patients with the Ultima MOM THA manufactured from wrought CoCrMo with a low carbon content in the femoral head.

In summary, although all the MOM-bearing implants in our study produced elevated serum levels of cobalt and chromium, we have shown that the serum concentration with a $28 \mathrm{~mm}$ MOM THA bearing is significantly lower than that seen with a MOM resurfacing. This finding may be of relevance when the potential for long-term side-effects of chronically elevated metal ions is considered. 
This study was funded by an unrestricted grant from Corin Surgical, Cirencester, Gloucester, UK.

\section{References}

1. McKee GK, Watson-Farrar J. Replacement of arthritic hips by the McKee-Farrar prosthesis. J Bone Joint Surg [Br] 1966;48-B:245-59.

2. Ring PA. Complete replacement arthroplasty of the hip by the ring prosthesis. J Bone Joint Surg [Br] 1968;50-B:720-31.

3. Muller ME. Total hip prostheses. Clin Orthop 1970;72:46-68.

4. Charnley J. The long-term results of low-friction arthroplasty of the hip performed as a primary intervention. J Bone Joint Surg [Br] 1972;54B:61-76.

5. Lombardi AV Jr, Mallory TH, Alexiades MM, et al. Short-term results of the M2a-taper metal-on-metal articulation. J Arthroplasty 2001;16 (8 Suppl 1):122-8.

6. Dorr LD, Wan Z, Longjohn DB, Dubois B, Murken R. Total hip arthroplasty with use of the Metasul metal-on-metal articulation: four to seven-year results. J Bone Joint Surg [Am] 2000;82-A:789-98.

7. Jin ZM, Dowson D, Fisher J. Analysis of fluid film lubrication in artificial hip joint replacements with surfaces of high elastic modulus. Proc Inst Mech Eng [H] 1997;211:247-56.

8. Medley JB, Chan FW, Krygier JJ, Bobyn JD. Comparison of alloys and designs in a hip simulator study of metal on metal implants. Clin Orthop 1996;(329 Suppl):148-59.

9. Chan FW, Bobyn JD, Medley JB, Krygier JJ, Tanzer M. Wear and lubrication of metal-on-metal hip implants. Clin Orthop 1999;369:1024.

10. Black J. In vivo corrosion of a cobalt-base and its biological consequences. In: Hildebrand HF, Champy M eds. Biocompatibility of $\mathrm{Co}-\mathrm{Cr}$ Ni alloys. NATO ASI Series, Plenum Press, 1988;83-100.

11. Smith SL, Dowson D, Goldsmith AA. The effect of femoral head diameter upon lubrication and wear of metal-on-metal total hip replacements. Proc Inst Mech Eng [H] 2001;215:161-70.

12. Brodner W, Bitzan P, Meisinger $\mathbf{V}$, et al. Elevated serum cobalt with metal-on-metal articulating surfaces. J Bone Joint Surg [Br] 1997;79B;316-21.

13. Sunderman FW Jr, Hopfer SM, Swift T, et al. Cobalt, chromium, and nickel concentrations in body fluids of patients with porous-coated knee or hip prostheses. J Orthop Res 1989;7:307-15.
14. Savarino L, Granchi D, Ciapetti G, et al. Ion release in patients with metal-on-metal hip bearings in total joint replacement: a comparison with metal-on-polyethylene bearings. J Biomed Mater Res 2002;63:467-74.

15. Versieck J, Cornelis R. In: Trace elements in human plasma or serum. Boca Raton, CRC Press, 1989.

16. Doherty AT, Howell RT, Ellis LA, et al. Increased chromosome translocations and aneuploidy in peripheral blood lymphocytes of patients having revision arthroplasty of the hip. J Bone Joint Surg [Br] 2001;83B:1075-81.

17. Shrivastava R, Upreti R, Seth P, Chaturvedi U. Effects of chromium on the immune system. FEMS Immunol Med Microbiol 2002;6:1.

18. Tharani R, Dorey FJ, Schmalzried TP. The risk of cancer following total hip or knee arthroplasty. J Bone Joint Surg [Am] 2001;83-A:77480 .

19. Jacobs JJ, Skipor AK, Doorn PF, et al. Cobalt and chromium concentrations in patients with metal on metal total hip replacements. Clin Orthop 1996;(329 Suppl):256-63.

20. Skipor AK, Campbell PA, Patterson LM, Amstutz HC, Jacobs JJ. Serum and urine metal levels in patients with metal-on-metal surface replacements of the hip. American Academy of Orthopaedic Surgeons Annual Meeting 2001, paper 270.

21. Witzleb WC, Hanisch U, Neumeister V, et al. Histopathological findings and metal ion concentrations in Metasul and Birmingham hip resurfacing metal on metal bearings. Engineers and Surgeons-joined at the hip: refining future strategies in total hip replacement 2002; volume 1:C601/040/2002

22. Nevelos J, Ingham E, Doyle C, et al. Microseparation of the centers of alumina-alumina artificial hip joints during simulator testing produces clinically relevant wear rates and patterns. J Arthroplasty 2000;15: 793-5.

23. Lombardi AV Jr, Mallory TH, Dennis DA, et al. An in vivo determination of total hip arthroplasty pistoning during activity. $J$ Arthroplasty 2000; $15: 702-9$.

24. Komistek RD, Dennis DA, Ochoa JA, Haas BD, Hammill C. In vivo comparison of hip separation after metal-on-metal or metal-on-polyethylene total hip arthroplasty. J Bone Joint Surg [Am] 2002;84-A: 1836-41.

25. Montero-Ocampo C, Rodriguez AS. Effect of carbon content on the resistance to localized corrosion of as-cast cobalt based alloys in an aqueous chloride solution. J Biomed Mater Res 1995;29:441-53. 